\title{
Sedimentation Rate and Characteristics of Musi River Mud, Palembang City, South Sumatra
}

\author{
Probowati Sulistiyani $^{1,2}$, Momon Sodik Imanudin ${ }^{1,2}$, and M Said ${ }^{2}$ \\ ${ }^{1}$ Soil Science Department Faculty of Agriculture Sriwijaya University, Palembang, South Sumatra, \\ Indonesia \\ ${ }^{2}$ Center for Environmental Studies Sriwijaya University, Palembang, South Sumatra, Indonesia
}

\begin{abstract}
The existence of the Musi River is very important not only for the population of South Sumatra, but also for the Bengkulu and Lampung regions. The main problem is the high rate of sedimentation, and the alleged increase in heavy metal content. The research aims were to determine the sedimentation rate and metal content in river mud in dry season. Samples of water, mud, and sediments were taken in the waters of Musi Hilir in the area around Kemarau Island in August-September 2018. The results of laboratory analysis showed that the river had been moderately polluted, where the ammonia content in the water was above the quality standard, and the Fe content in the mud is classified as high (above the quality standard). The sediment accumulation in the nine samples at three stations showed at Station 1 was $0.022429739 \mathrm{~g} \mathrm{~cm}^{-1}$ day $^{-1}$. The highest accumulation rate of sediment weight was found at Station 2 which was $0.038456224 \mathrm{~g} \mathrm{~cm}^{-1} \mathrm{day}^{-1}$. The lowest sediment accumulation rate was found at Station 3, which was only $0.007109631 \mathrm{~g} \mathrm{~cm}^{-1} \mathrm{day}^{-1}$. The cause of the low accumulation of sediment at Station 3 was due to flow velocity at this location tends to be large, so that the sediment was difficult to settle. If the assumption was four months dry season, the accumulation of sediment was estimated at 26.9 tons $/ \mathrm{m}^{2}$ 14 months.
\end{abstract}

Keywords: Sedimentation rate; Musi River, mud.

\section{INTRODUCTION}

The Musi River is a river that is the estuary of dozens of other large and small rivers, both in Bengkulu and South Sumatra. This river has a length of about $720 \mathrm{~km}$ and crosses the city of Palembang. Various industrial activities such as mining, plantations, agriculture, household activities, as well as natural activities that enter the river water have an impact on aquatic biota and health. The activities also resulted in exposure of heavy metals such as $\mathrm{Hg}$ to the river body (Setiawan, 2013). On the other hand, the Musi River is a river with high economic values, because this river functions as a connecting line between the sea and the land. The existence of silting in the river mouth can result in the obstruction of the traffic for fishing boats and passenger ship

Correspondence Author: Momon Sodik Imanudin. Soil and Water Conservation Laboratory, Department of Soil Science, Faculty of Agriculture, Sriwijaya University, Indonesia, Email: momon_unsri@yahoo.co.id during low tide. On the contrary, when sea water experiences flooding, the water overflows above the river lip so that the area around the village experiences flooding.

Reported by the Tribune of South Sumatra (2010) that silting up the Musi River was a serious threat because it was estimated that sedimentation reaches $50 \mathrm{t}$ day $^{-1}$. So that the river flow had silted and would hamper ships traffic flow. The normalization costs are very large, reported by PT Pusri for dredging the mud at the Musi River cost five billion year. It was estimated that three million cubic $\mathrm{m}$ year ${ }^{-1}$ of sediment accumulation occur at the mouth of the Musi River (Kompas, 2010). For dredging, PT Pelindo must spend up to Rp 16 billion every year. On the other hand, the capacity of the river continues to decline so that the potential for flooding in the downstream such as the city of Palembang becomes large. According to previous research, the velocity of the Musi river downstream flow ranged from 0.4 to $0.5 \mathrm{~m} \mathrm{sec}^{-1}$ which resulted in a 
discharge between 600 to $700 \mathrm{~m}^{3} \mathrm{sec}^{-1}$. Besides being influenced by velocity rate of river flow, the sedimentation rate was also influenced by the shape of the riverbed reliefs, the slope level, the extent and condition of the watershed season, and human activities (Chakrapani, 2005). Added by William (2012), that the sediment rate is strongly influenced by vegetation cover, climatic conditions and regional geology and seasons. Sediment rates increased 20 times higher in December compared to April-May (Moriarty, et al., 2018).

Regarding the decrease in water capacity in the Musi River, a study was needed to determine the seasonal sedimentation rate and sediment movement patterns, so that it can provide an alternative solution to siltation problems and estuarine narrowing which causes flooding in the upper reaches of the river. Alternative solutions to this silting problem were needed as an effort to reduce the greater losses. Another factor was the alleged increase in heavy metal content in riverbed loads. This condition will affect the quality of water and aquatic biota which is certainly harmful to humans as consumers.

The purpose of this study is to build a sediment control model in the Musi River waters. For the initial stage:

1. Calculate the amount of sediment that occurs in the lower waters of the Musi River in several bathymetric conditions and variations in flow velocity

Calculate the amount of sediment volume for one year in the area around the dry island in the Musi River waters

\section{RESEARCH METHODS}

The study was conducted in the waters of the Musi River in the lower part of Palembang (Kemarau Kemaro Island). Field survey activities started from July to August 2018. Laboratory analysis was carried out from August to October 2018. The sampling area can be seen in Figure 1.

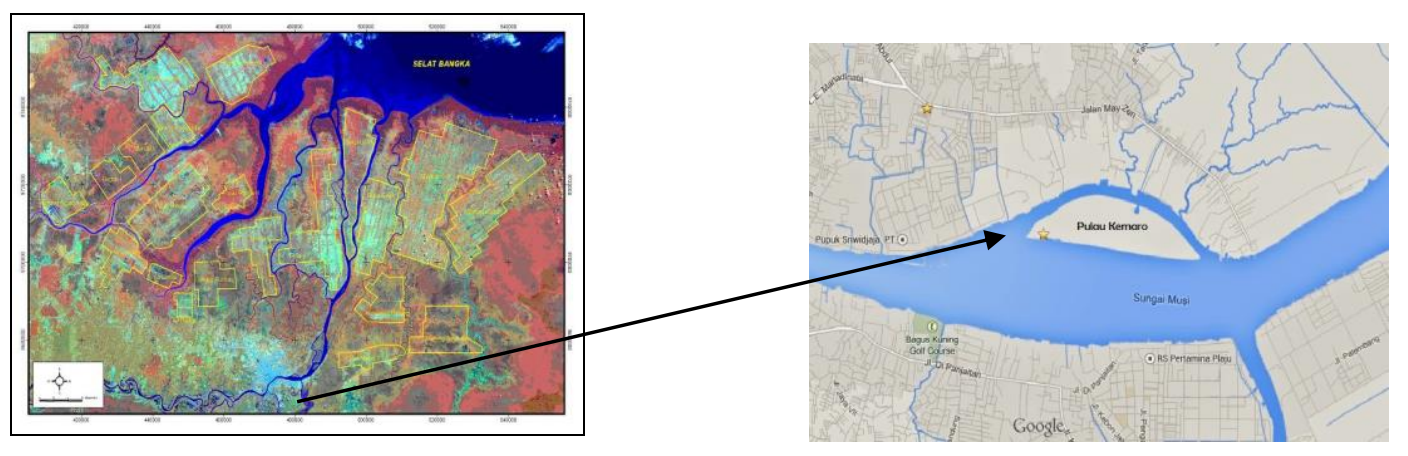

Figure 1. Map of the situation for planned sediment sampling

The tools and materials needed in the study were current meter, floating sediment catchers, sediment settling, buoys, GPS, peilschaal boards, and measuring tape. For transportation, small boats were used.

Sludge sampling was carried out at three representative area points near the river embankment and the river middle section. Laboratory analysis of sludge includes types of soil texture, $\mathrm{pH}, \mathrm{Cu}, \mathrm{Fe}$, and $\mathrm{SO}_{4}$.
To determine the content of suspended sediments, water samples were analyzed using the APHA method in Alaerts and Santika (1987).

$$
M P T=\frac{(a-b) \times 1000}{V}
$$

Where :

MPT $=$ suspended sediment concentration $\left(\mathrm{g} \mathrm{mL}^{-1}\right)$ 
$\mathrm{a}=$ filter paper weight and residue after heating $(\mathrm{g})$

$\mathrm{h}=$ filter paper weight after heating $(\mathrm{g})$

$\mathrm{V}=$ volume of filtered sample water $(\mathrm{mL})$

Sediment discharge from the river can be predicted using the general equation of the relationship between the discharge of river runoff and sediment discharge from the river, which is formulated as follows:

$Q_{s}=Q C_{s}$

Where: $\left.\mathrm{L}^{-1}\right)$

Qs: sediment discharge from the river (mg
Q: river water runoff discharge $\left(\mathrm{m}^{3} \operatorname{det}^{-1}\right)$

Cs: sediment concentration $\left(\mathrm{mg} \mathrm{L}^{-1}\right)$

Sediment trap was used to measure the accumulation rate of sediment. Sediment trap measured the amount or volume of sediments accumulated. This tool can be placed at the desired depth according to the purpose of the research conducted. In this study, sediment trap was placed at a depth of two $m$. The sediment trap design can be seen in Figure 2. This tool had been scientifically tested (Szmytkiewicz and Zalewska, 2014).

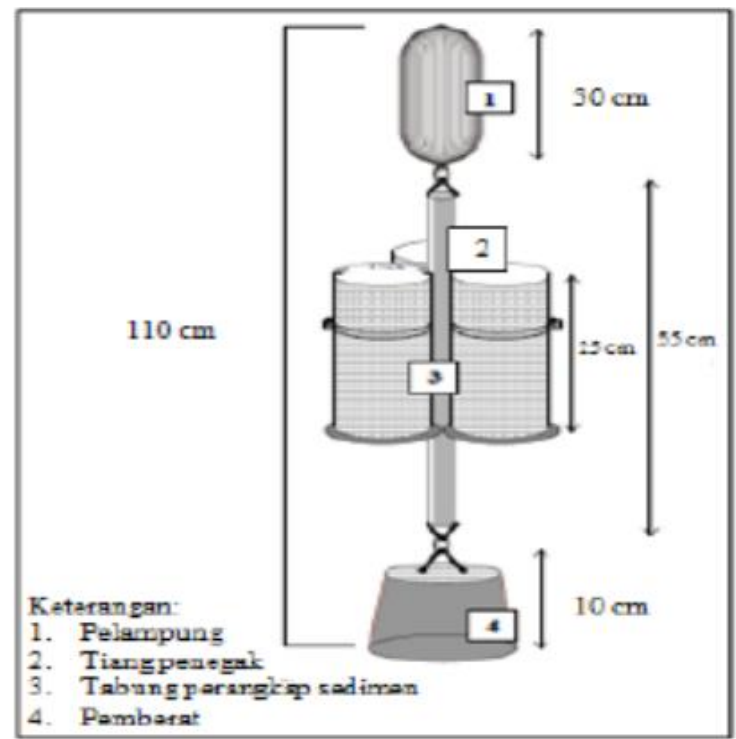

Figure 2. Sediment Trap Design (Aritonang et al., 2014).

The steps for analyzing sediment samples were carried out several things, as follows:

1. Sediments obtained from each sediment trap were taken and put in a plastic bag.

2. Samples were analyzed in the laboratory to determine the weight

3. The sample was dried by drying it in the sun

4. The dried sample was weighed

5. Calculate the amount of sediment weight per tube cross-sectional area per unit time (days).

The analysis of accumulated sediment samples calculated was the weight of sediments deposited by unity of area per time based on Rifardi (2012) as follows:

Rate $=(\mathbf{W} / \mathbf{L}) / \mathbf{t}$

Sediment Accumulation Weight

Journal of Wetlands Environmental Management

Vol 7, No 1 (2019), 95 - 105

http://dx.doi.org/10.20527/jwem.v7.v1.192 where:

Accumulated Weight Rate $=($ gram $/ \mathrm{cm} 2 /$ day) ( $\mathrm{g} \mathrm{cm}^{2}$ day $^{-1}$

$\mathrm{W}=$ Sediment Dry Weight $(\mathrm{g})$

$\mathrm{L}=$ Cross-sectional area of Sediment trap $\left(\mathrm{cm}^{2}\right)$

$\mathrm{t}=$ Sediment trap (days) Installation Time

\section{RESULTS AND DISCUSSION}

\section{Characteristics of the Musi River}

Downstream of the Musi River is a meeting place with the Komering River with a river flow of $2,500 \mathrm{~m}^{3} \mathrm{sec}^{-1}$ which changes in the dry season and the rainy season between 1,400 to $4,200 \mathrm{~m}^{3} \mathrm{sec}^{-1}$. Usually, the flow from the Musi River and its tributaries 
reaches a maximum between February and March, and the minimum is from July to September.

The water level of the Musi River is +1.2 $\mathrm{m}$ above sea level and the highest is around $+0.0 \mathrm{~m}$ during the dry season. In the rainy season, the water level of the Musi River is $+1.8 \mathrm{~m}$ above sea level as the maximum height and average height of $+1.0 \mathrm{~m}$. The maximum height at high tide can reach up to $+3.3 \mathrm{~m}$ at Talang Buyut Station at the mouth of the Musi River. In general, the maximum tide occurs from December to June and the minimum tide occurs from March to September.

The availability of the Musi River is greatly influenced by the shipment of water from the upstream area where the Musi River basin is. So that monthly rainfall is very influential on Musi River flow discharge. The Musi River receives water from parts of Bengkulu and empties into nine tributaries, namely: Komering, Rawas, Batang hari, Leko, Lakitan, Kelinci, Lematang, Semangus, and Ogan rivers. JICA (2003) reported that approximately $30 \%$ of the Musi River Basin had been damaged, resulting in a rapid rise of the water level in the rainy season and high sedimentation in the downstream area caused by erosion in the upstream watershed. Meanwhile in the dry season, saltwater intrusion symptoms have occurred to the Kemarau Island. This is because the water discharge from the upstream part is reduced quite significantly compared to the rainy season. Besides, there has been damage to mangroves in the coastal area. As a result, the pressure of sea water deepens and makes some of the river area become brackish. If it is not immediately resolved, it is feared Palembang will have difficulties in fresh water.

\section{Contents of Suspended Sediment and Sediment Discharge}

Musi River water analysis results in dry season conditions (August) is can be seen in
Table 1. Table 1 shows good results of all chemical parameters meeting irrigation water quality standards. Water quality was relatively good in the period of the dry season. Physically, the water was not cloudy because the load of dissolved solid was relatively small. This condition occurs because of the dry season, so that the dominant river water source comes from underground flows, not from surface runoff that carries a lot of material due to erosion. The TSS (total suspended solid) content dissolved is only in the range of 15 to $10 \mathrm{mg}$ $\mathrm{L}^{-1}$, still far below the quality standard.

The low value of dissolved solids was because there was no rain in the upstream watershed. This was in line with the research of Mouri et al. (2014) that in dry conditions the value of dissolved solids ranges from 10

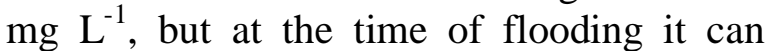
reach $1400 \mathrm{mg} \mathrm{L}^{-1}$.

The parameter that above the quality standard was $\mathrm{NH}^{3}$ levels which was at the level of 0.64-0.69 $\mathrm{mg} \mathrm{L}^{-1}$ (Table 1), while the quality standard is only in the range of 0.05 $\mathrm{mg} /$ liter. This condition is in line with the research of Windusari and Permata Sari, (2015) that showed the results of measurement of ammonia levels in the waters of the Musi river, there were a range of $0.8-0.9 \mathrm{mg} /$ liter. The presence of ammonia in river water that exceeds the threshold can disrupt aquatic ecosystems and other living creatures. Ammonia is very toxic to almost all organisms. Ammonia can be toxic to humans if the amount that enters the body exceeds the amount that can be detoxified by the body. In humans, the biggest risk is from inhalation of ammonia vapor which results in several effects including irritation of the skin, eyes and respiratory tract. At a very high level, inhalation of ammonia vapor is very fatal. The concentration of ammonia will increase if it is dissolved in the water and causes poisoning for almost all aquatic organisms (Murti, et al 2014). 
Floating load (suspended load) is a particle that moves in a vortex of flow that tends to continue to float along the flow. The particle size is smaller than $0.1 \mathrm{~mm}$. The load of the floating sediments moves along with the river water flow, consisting of fine sand which is always supported by water, and has very little interaction with the river bed because it has been pushed up by flow turbulence. According to the study of Pourhosein et al., (2015) the value of bed load is around $2.70 \%$ of suspended sediment load.

Table 1. Results of analysis of the quality of water in the lower Musi River near Kemarau Island

\begin{tabular}{llllll}
\hline \multirow{2}{*}{ No } & \multirow{2}{*}{ Parameter } & Unit & \multicolumn{2}{l}{ Sampling code } & \multirow{2}{*}{$\begin{array}{l}\text { Standard } \\
\text { quality }\end{array}$} \\
\cline { 4 - 5 } & & $\mathbf{7 0 8}$ & $\mathbf{7 0 9}$ & \\
\hline 1. & $\mathrm{pH}$ & Unit & 6.97 & 7.04 & $6-9$ \\
2. & TDS & $\mathrm{mg} \mathrm{L}^{-1}$ & 57.5 & 57 & 1000 \\
3. & COD* & $\mathrm{mg} \mathrm{L}^{-1}$ & $26 / 103$ & 31.198 & - \\
4. & M\&L & $\mathrm{mg} \mathrm{L}^{-1}$ & 0.04 & 0.045 & 1 \\
5. & Ammonia $\left(\mathrm{NH}_{3}\right)$ & $\mathrm{mg} \mathrm{L}^{-1}$ & 0.637 & 0.669 & 0.05 \\
6. & Sulfate $\left(\mathrm{SO}_{4}\right)$ & $\mathrm{mg} \mathrm{L}^{-1}$ & 17.903 & 17.889 & 400 \\
7. & Phosphate $\left(\mathrm{PO}_{4}\right)$ & $\mathrm{mg} \mathrm{L}^{-1}$ & 0.04 & 0.045 & 0.2 \\
8. & TSS & $\mathrm{mg} \mathrm{L}^{-1}$ & 15 & 10 & 50 \\
\hline
\end{tabular}

If the Musi River discharge in dry conditions is in the range of $800 \mathrm{~m} 3 / \mathrm{s}$ and the floating sediment concentration (TSS) is an average of $12.5 \mathrm{mg} \mathrm{L}^{-1}$, then in $1 \mathrm{~m}^{3}$ water will carry sediment of $12,500 \mathrm{mg}$ or equivalent to $12.5 \mathrm{~g}$. And for the water debit $925 \mathrm{~m}^{3} \mathrm{sec}^{-1}$ will carry $5821.2 \mathrm{~kg} \mathrm{day}^{-1}$ of sediment or $5.82 \mathrm{t} \mathrm{day}^{-1}$ transported in the Musi River waters during the dry season.

\section{Characteristics of several chemical parameters of Musi River Mud}

River sludge was an indicator that the Musi River has been degraded due to the sedimentation process. For the restoration of drainage systems and shipping lines, dredging must be carried out. The dredging results will be used for landfill, or can be used for plant planting media. For this reason, several heavy metal parameters are analyzed so that the planting media is not harmful to the health of the soil and plants. The results of the analysis of chemical

Journal of Wetlands Environmental Management

Vol 7, No 1 (2019), 95 - 105

http://dx.doi.org/10.20527/jwem.v7.v1.192 characteristics of sludge can be seen in Table 2.

The copper metal can enter all strata of the environment, be it in the water, soil or air strata (atmospheric layer). Copper included in all three strata of the environment can come from various sources. But the sources of $\mathrm{Cu}$ input into the general environmental strata are thought to be the most from industrial activities, household activities and from burning and fuel mobility (Liantira, 2015)

Table 2. shows the results of mud analysis where some parameters are feasible and harmless. For example, $\mathrm{Cu}$ content shows the number $0.01 \mathrm{mg} \mathrm{kg}^{-1}$. The figure is relatively low because the threshold for drinking water is $0.02 \mathrm{mg} \mathrm{kg}^{-1}$. if the value of $\mathrm{Cu}$ is at 2.5 $\mathrm{mg} \mathrm{kg}^{-1}$, it will result in polluting and killing aquatic biota. The existence of $\mathrm{Cu}$ elements in nature can be found in the form of free metals, but more are found in the form of compounds. Copper is included in the essential metal group, where low levels are needed by organisms as coenzymes in the 
body's metabolic processes, the nature of the toxin appears only at high levels. According to Palar (2004) at a concentration of 0.01 ppm phytoplankton will die because $\mathrm{Cu}$ inhibits enzyme activity in phytoplankton cell division. The $\mathrm{Cu}$ concentration in the range of 2.5-3.0 ppm in water bodies will kill fish.

Table 2. Chemical characteristics of Musi River mud

\begin{tabular}{llllll}
\hline No & Parameter & Unit & $\begin{array}{c}\text { Sampling } \\
\text { code } \\
\mathbf{7 1 0}\end{array}$ & $\begin{array}{c}\text { Standard } \\
\text { quality }\end{array}$ & Method \\
\hline 1. & $\mathrm{pH}$ & Unit & 6.3 & $6-9$ & SNI 06.6989.11-2004 \\
2. & $\mathrm{Cu}^{*}$ & $\mathrm{mgkg}^{-1}$ & 0.01 & - & SNI 6989.6-2009 \\
3. & $\mathrm{Fe}$ & $\mathrm{mgkg}^{-1}$ & 23.01 & - & SNI 6989.4-2009 \\
4. & $\mathrm{SO}_{4}$ & $\mathrm{mg} \mathrm{kg}^{-1}$ & 1.522 & - & SNI 06.6989.20-2009 \\
\hline
\end{tabular}

The Health Ministry of the Republic of Indonesia has established Republic of Indonesia Minister of Health Regulation Number 416/MENKES/PER/IX/1990, concerning the requirements and supervision of water quality, that the maximum $\mathrm{Fe}$ content permitted for clean water is $1 \mathrm{mg} \mathrm{L}^{-1}$. For example, Lapindo mud has an $\mathrm{Fe}$ content that far exceeds the threshold, which is 22.416-25.434 $\mathrm{mg} \mathrm{L}^{-1}$ so that over time it will be able to pollute the residents' well water (Putrid an Yudhastut, 2013). This is corresponding with research done by Supriyantini, E and Hadi Endrawati (2015) that found the average content of $\mathrm{Fe}$ in sediments in the estuary area of Tanjung Emas Semarang was 27,945 $\mathrm{mg} \mathrm{kg}^{-1}$. Quality standards issued by the United States Environmental Protection Agency (USEPA) that sediments in the range of $17-25 \mathrm{mg} \mathrm{kg}^{-1}$ are classified as moderately polluted sediments. Therefore, because of the pretty high amount of Fe, the mud of Musi River was classified into the medium polluted class.

The high content of Fe in the estuary is thought to be caused by the $\mathrm{Fe}$ content originating from several sources, that is, aside from the soil, it also comes from human activities that occur on land, namely iron-containing household waste, iron water reservoirs, sediments industrial waste and corrosion from water pipes containing iron metal carried by the river flow to the estuary. The technology for reducing Fe content in water can be done by giving coal fly ash (Jamali, 2017). The main components of fly ash are $\mathrm{Si}, \mathrm{Al}, \mathrm{Fe}(\mathrm{OH})_{2}, \mathrm{Ca}(\mathrm{OH})_{2}$, and residual-C. So this material can also be used for reducing the F levels (Ranjeeta, 2015).

Reported by Rachman, and Chaerul. (2015), the utilization of river mud can be used as the main ingredient in compost. Soil mud mixed with rice straw into compost which is very good for plant media.

\section{Study of the speed of the Musi River flow}

The results of flow velocity analysis can be seen in Table 3. The average flow velocity is $0.078 \mathrm{~m} \mathrm{sec}^{-1}$. The value of this flow velocity is directly proportional to the discharge. The higher the flow velocity value, the higher the debit value.

\section{Perfomance Improvement of Water Management Network}

The results of current measurements in the field obtained the maximum current speed reaching speeds of $0.11 \mathrm{~m} \mathrm{~s}$ and the minimum speed ranged from $0.045 \mathrm{~m} \mathrm{sec}^{-1}$. 
where the current moves from the west of the Musi River towards the east past through Kemaro Island. There was an increase in the speed of the flow in the south direction of Kemaro Island to 0.1 until $0.11 \mathrm{~m} \mathrm{sec}^{-1}$ towards the east due to the narrowing of the cross-sectional area and the existence of the island and also due to the influence of bathymetry which only has a depth of $<5 \mathrm{~m}$.

The results of flow velocity measurements indicate that the speed of flow was getting slower the closer it gets to the riverbed. This decrease in speed allows for an increase in the particle's decreasing power for sediment. The decreasing flow velocity conditions

Table 3. Results of flow velocity measurements in the Musi River

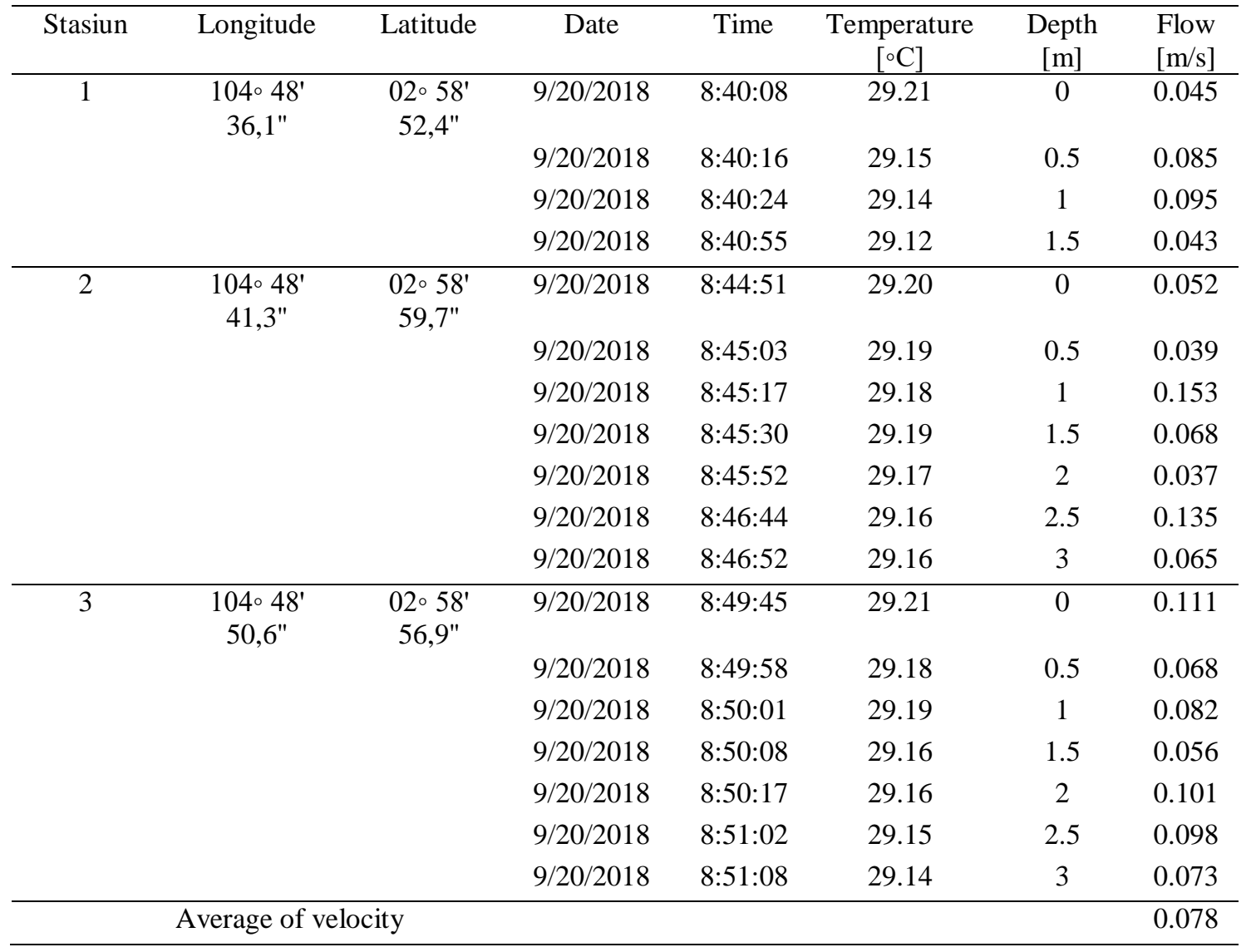

were clearly influenced by the cross section of the river segment. The closer to the dry island the river segment becomes wider. The cross-sectional area of the river segment near the island of dry season was around $1850 \mathrm{~m}^{2}$ using the average flow rate of $0.1 \mathrm{~m} \mathrm{sec}^{-1}$ so that it only produces a flow of $185 \mathrm{~m}^{3} \mathrm{sec}^{-1}$. During high tide conditions, the movement of the Musi River tends to move from east to west (into the Musi River). Whereas during low tide conditions, the mass of water moves from west to northeast (towards estuary) because tides are affected by a combination of gravitational forces and the attraction of astronomical objects, especially by the sun, earth and moon.

Current movement patterns tend to be based on current velocity caused by tides. The tidal type in the study site is diurnal type where in this type occurred one time of high tide and one time of low tide in one day. This was in accordance with a statement from Surbakti (2012) wherein the study stated that in the Musi River waters, the tidal type in the 
waters of the Musi River was single diurnal with a Formzahl number of 3.06. The pattern of flow (flow) can be seen in Figure 3.

Flow describes the power of energy that will carry particles of sediment and its distribution in the waters, so that currents greatly affect sedimentation. Flow is also a force that determines the direction and distribution of sediments. The direction of the current in the observation area leads eastward through Kemaro Island so that it will affect the rate of sediment accumulation. When the water flow meets with turbulence, there will be a speed of flow.

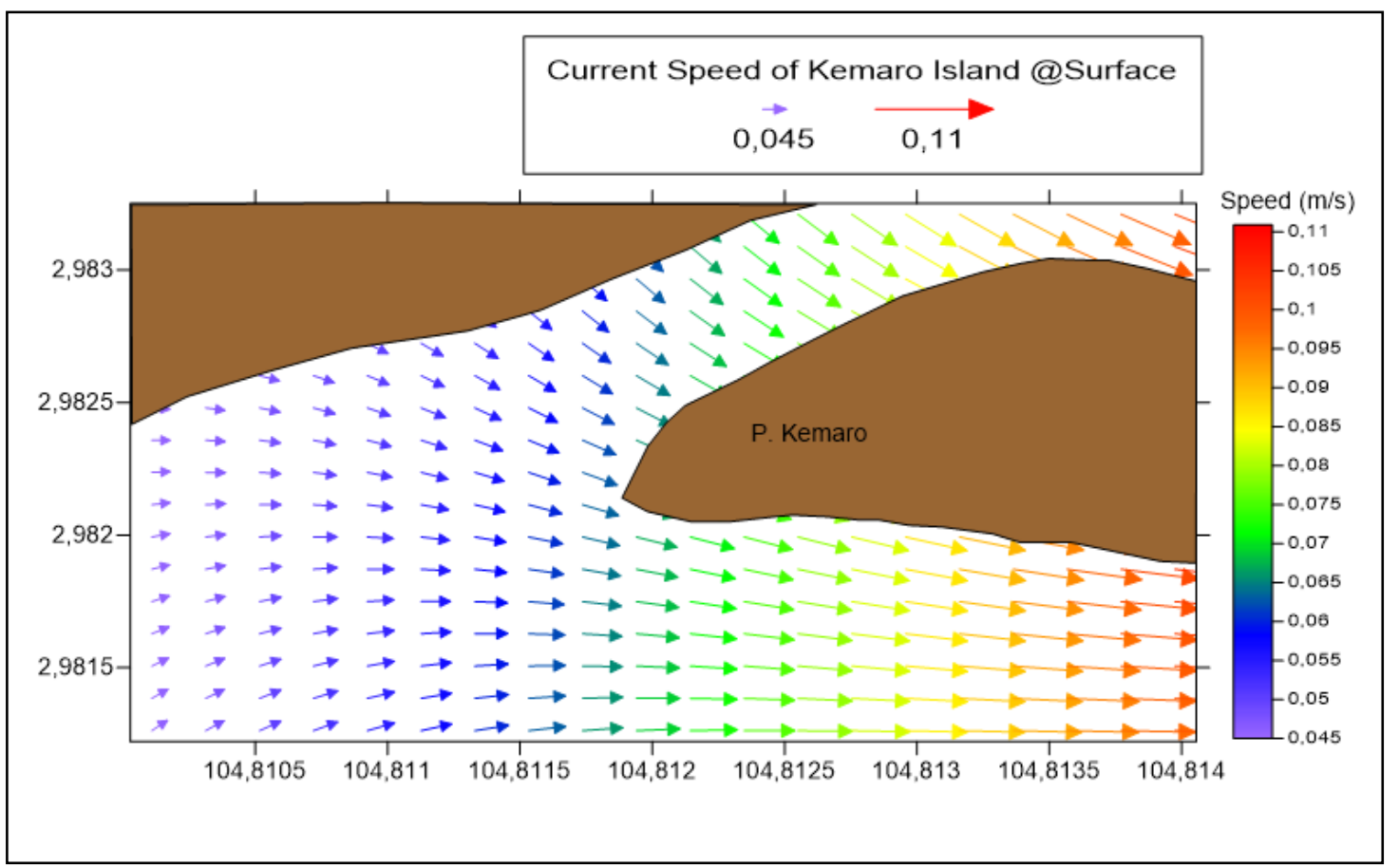

Figure 3. Pattern of direction of flow in Musi waters near the dry island.

The temperature of musket processing in August to September has increased due to dry conditions. The result of direct measurement of water temperature was at level $29.1{ }^{\circ} \mathrm{C}$. This condition indicates an increase in temperature was possible due to global heating. Even though in 1932, in the era of the Dutch government the measurement results of the Musi River showed temperatures in the range of 25 to 27 ${ }^{\circ} \mathrm{C}$. Chemicals released by industrial wastes such as heavy metals in the river result in increased temperatures in these waters (Kristanto, 2002).

From the results of the observations obtained the results of the average weight of Journal of Wetlands Environmental Management Vol 7, No 1 (2019), 95 - 105 http://dx.doi.org/10.20527/jwem.v7.v1.192 sediment accumulation in the waters of the Musi River estuary precisely around Kemaro Island was around $0.022429739 \mathrm{~g} \mathrm{~cm}^{2}$ day $^{-1}$. The highest accumulation rate of sediment was found at station 2 which was equal to $0.038456224 \mathrm{gr} / \mathrm{cm}^{2} /$ day. At the location of observation station 2 at the time of trap capture after one week installation, it can be seen that a delta buildup was occurred around the location. This is assumed to cause the result of sediment accumulation in trap 2 was also higher than other stations. The lowest sediment accumulation rate was found at Station 3, where at Station 3 only found around $0.007109631 \mathrm{gr} / \mathrm{cm}^{2} /$ day. The cause of the low accumulation at this 
location is indicated because the current velocity at this location also tends to be large, so the sediment is difficult to settle. The average accumulated sedimentation rate is $0.0224 \mathrm{gr} / \mathrm{cm}^{2} /$ day, or equal to $2.69 \mathrm{~kg} \mathrm{~cm}$ 4 months $^{-1}$. The duration of four months was the assumption of the length of the dry season where the water quality of the Musi River was relatively good. When converted into a square meter area, in $1 \mathrm{~m}^{2}$ it can produce 26.9 t4-months-1. Meanwhile, to calculate the annual sedimentation rate must obtain measurement data in the rainy season. The study by Bella (2014) on the Banyuasin River estuary showed a sedimentation rate of 267.4211 (lb/yr.) / ft or equivalent to $1.337,1$ $\mathrm{kg} /$ year $/ \mathrm{m}^{2}$. While the study of Aritonang et al (2014) states sediment deposition rate for Anakan Island Muara Sungai Banyuasin, South Sumatra ranged from $1.421 \times 10^{-10} \mathrm{~m}^{3}$ $\mathrm{sec}^{-1}$ to $2.645 \times 10^{-11} \mathrm{~m}^{3} \mathrm{sec}^{-1}$.

Table 3. Results of calculation of sedimentation rates in the waters of the Musi River

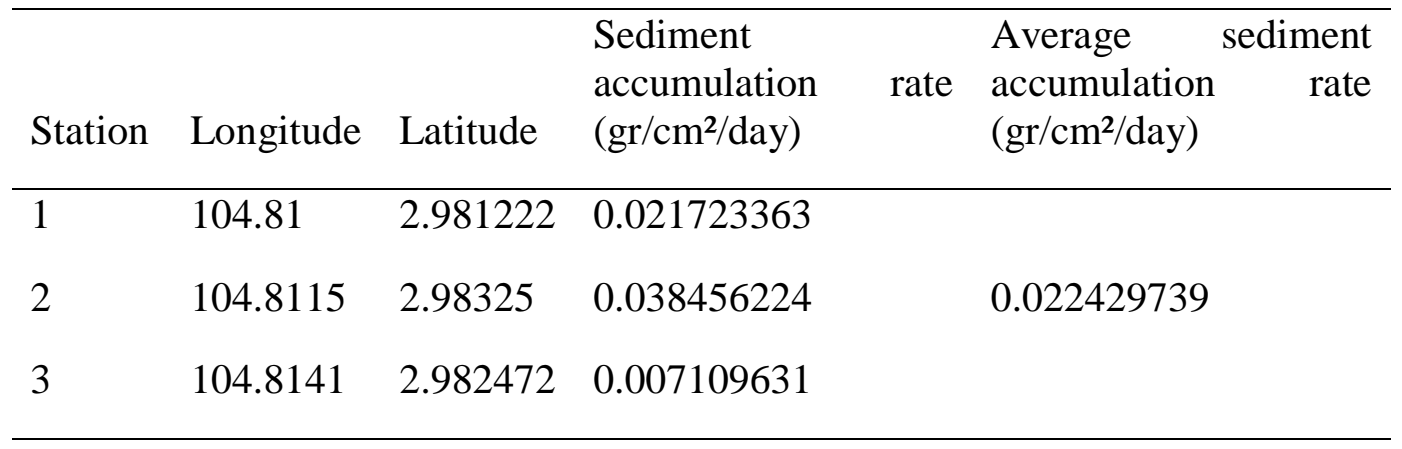

The current velocity affects the accumulation of sediment that occurs, the condition of the strong current velocity will reduce the amount of accumulation because the sediment does not have the chance of time to settle and will be carried away from the source. Sediments generated from the erosion process and carried by the flow of water will be deposited in a place where the flow velocity slows or stops. This deposition event is known as the sedimentation process. This process runs very complex, starting from the fall of rain that produces kinetic energy as the beginning of the erosion process then the soil becomes fine particles, then rolls along the flow, some are left on the ground while others enter the river carried by the flow into sediment transport (Mokonio, 2013). A Research by Szmytkiewicz and Zalewska (2014) states that the sediment rate is influenced by the season. The condition of the sediment rate reached its highest in the
January and early February periods and the minimum in June and August.

\section{CONCLUSION AND RECOMMENDATION}

\section{Conclusions}

Based on the results of field studies and laboratory analysis of this study, some conclusions and suggestions can be taken, namely:

- The temperature of musket processing in August-September has increased, due to dry conditions. The result of direct measurement of water temperature is at level $29.1^{\circ} \mathrm{C}$

- Calculation of sediment discharge in the waters of the lower part of the Musi River (Kemarau Island) was 5.82 tday $^{-1}$, this occurs in the dry season in September 2018. 
- Sediment accumulation in the waters of the Musi River estuary around the Kemaro Island is approximately $0.022429739 \mathrm{gcm}^{-2} \mathrm{day}^{-1}$. The highest accumulation rate of sediment was found at station 2 which was equal to $0.038456224 \mathrm{gr} / \mathrm{cm}^{2} /$ day. The lowest sediment accumulation rate was found at Station 3, where at Station 3 only found around $0.007109631 \mathrm{gr} / \mathrm{cm}^{2} / \mathrm{day}$. The cause of the low accumulation at this location is indicated because the current velocity at this location also tends to be large, so the sediment is difficult to settle. If the dry season assumption is 4 months, the sediment accumulation is $26.9 \mathrm{tm}^{-2} 4$ months $^{-1}$.

- The Fe content of sediments in the Kemaro Island area of the Musi River was $23.0 \mathrm{mgkg}^{-1}$. When referring to the quality standards issued by the United States Environmental Protection Agency (USEPA) that sediments in the range of 17 to $25 \mathrm{mg} \mathrm{kg}^{-1}$ were classified as moderate polluted sediments.

- For $\mathrm{Cu}$ content shows the number 0.01 $\mathrm{mg} / \mathrm{kg}$. The figure was relatively low because the threshold for drinking water is $0.02 \mathrm{mg} / \mathrm{kg}$.

- Analysis of fertility from river mud shows materials of the mud does not contain harmful substances for agricultural cultivation. The level of acidity is quite moderate, and the aluminum content was low. Some macro parameters show a moderate value so that the soil fertility status is medium.

\section{Recommendation}

Several suggestions generated from this study include:

- For the use of mud as a medium for growing plants, efforts to reduce $\mathrm{Fe}$ levels are needed. Research is needed to add substances that can reduce Fe levels.

- Further research is needed so that river mud can be used for agriculture. Through a composting method, there will be a volume reduction of $40 \%$. Well-composted bio-solid is generally used as a soil conditioner in agriculture and plantations.

- The results of analysis of sediments and chemical parameters of water indicate that during the dry season conditions the water was good, so research is needed for the conditions of the rainy season. Dry and rainy season data can be used as a reference for the total annual sedimentation generated from the Musi River flow.

- Annual sediment accumulation has not been calculated because new research was conducted in the dry season, so there will be a measurement in advance to see the rate of sedimentation in the rainy season. The second measurement plan is on January 2019.

\section{REFERENCES}

Aritonang, A.E., Heron S and Anna I, Sunaryo P. 2014. Sediment Deposition Rate on Anakan Muara Island, Banyuasin River, South Sumatra. Maspari Journal 6 (2). 133-141 p.

Chakrapani, G. J. 2005. Factors controlling variations in river sediment loads. Current science, vol. 88 (4) 569-575 p.

Effendi, H. 2003. Review of Water Quality for Management of Resources and Aquatic Environment. Kanisius Publisher. Yogyakarta.

Junaidi, F.F. 2014. Analysis of Distribution of Musi River Flow Speed (Ampera Bridge Section to Kemaro Island. 2014. Journal of Civil and Environmental Engineering Vol. 2.No.3, September 2014

Kompas, 2010. Siltation of the Musi River Disrupts Shipping. Downloaded from. https://bola.kompas.com/read/2010/02/0 8/03311496/pendangkalan.sungai.musi. mengganggu.pelayaran 
Kompas, 2010. The river water quality in Musi Bad is downloaded at https://travel.kompas.com/read/2010/02/ 04/04311097/Kualitas.Air.Sungai.Musi. Buruk.

Feirani. V. 2011. Analysis of Stability of Blockage of River Estuary due to the phenomenon of Wave, Tidal, Danv River Flow Sediment Movement Pattern at Bang River Estuary, Malang Regency, Universitas Brawijaya.

Fawel, J.K., Lund, U., Mintz, B. 1996. Guidelines for Drinking Water Quality. 2nd ed Vol.2. Health Criteria and other Supporting

Multi, R.Setiya and C. Maria H.P. 2014. Optimizion of the Formation Time of a Stable Indofenol Blue Complex on $\mathrm{N}$ Ammonia Test of Wastewater Tannery Industry with Fenat Method. Leather, Rubber and Plastic Magazines Vol. 30 No.1 June 2014: 29-34

Ranzeeta (2015) Removal of Fluoride from Drinking Water Using Fly Ash after Pre Treatment. J Environ Anal Toxicol S7: 004. doi: 10.4172 / 2161- 0525.S7-005

Rachman, A.N. and Chaerul., M. 2015. Preliminary studies on the utilization of Ciliwung river mud around the Istiqlal mosque with composting. Journal of Environmental Engineering 21 (1) 9$17 \mathrm{p}$.

Szmytkiewicz, A., Tamara Z. 2014. Sediment deposition and accumulation rates were determined by sediment traps and $210 \mathrm{~Pb}$ isotope methods in the Outer Puck Bay (Baltic Sea). OCEANOLOGIA, 56 (1), 2014 pp. 85106.

Setiawan, A, A., Emilia, I., Suheryanto. 2013. Total Mercury content in various types of fish in the waters of the Musi River in Palembang City. Journal of the National Science and Technology Seminar at the Lampung University Research Institute.

Seconds, 2006. Dozens of Fish on the Musi River Die Due to Ammonia Disposal. Downloaded from https://news.detik.com/berita/552518/pu luhan-ikan-di-sungai-musi-mati-akibatpembuangan-amoniak

Tribune, 2010. Musi River Sedimentation Reaches 50 tons per day. Downloaded http://palembang.tribunnews.com/21/05/ 2010/sedimentasi-sungai-musi-capai-50ton-per-

Windusari, Y., Neta., P. 2015. Water Quality of the Musi River in Palembang City, South Sumatra. Bioeskperimen 1 (1) 1$5 p$.

William, M.B. 2012. River sediments. Philosophical Transaction. Royal Society (2012) 370, 2093-2122.

Wahyudi and Dikantara Jupantara. 2004. Study of Sedimentation Simulation Due to Development of Tanjung Perak Port in Surabaya. Journal of Marine Technology Vol. 8, No. 2, July 2004: 74 $-85$ 